\title{
Structure and dynamics
}

of populations

The 'years-to-live' pyramid,

national aspects and regional examples.

\section{Nicolas BROUARD}

Translated by Tim Riffe ${ }^{\dagger}$ from the original French language article with help from the original author:

Brouard, Nicolas (1986) Structure et dynamique des populations. La pyramide des années à vivre, aspects nationaux et exemples régionaux Espace, Populations, Sociétés vol.4 n², pp. 157-168, doi: 10.3406/espos.1986.1120.

The original French text is in the left column for reference and the new translation is on the right. In the original 1986 publication, Figure 10 was misplaced at the beginning of the article, and some captions were missing. We fixed these details and enlarged some of the original French figures for more legibility. Only the captions have been translated. Some comments are given in the English translation in square brackets for clarification. The theorem mentioned in section 1.1 was also published in French in 1985 in a separate mogograph. An English translation of the section containing its proof is given in an Appendix. March, 2018

† Max-Planck-Institute for Demographic Research ～～riffe@demogr.mpg.de

Dans les études démographiques et plus généralement dans le domaine de la statistique, le sens positif du temps est privilégié. Nous voulons dire par là, qu'une probabilité conditionnelle est toujours conditionnée par un événement antérieur à la date actuelle : le mariage conditionne (conditionnait) la venue des enfants. Est-il impensable que nos agissements d'aujourd'hui soient en partie conditionnés par des évènements futurs ? Un couple pour lequel un divorce est proche n'a-t-il pas une probabilité moindre de donner naissance à des enfants aujourd'hui ? La variable importante à prendre en compte est la durée qui sépare du divorce futur ; et celle-ci a peut-être un pouvoir explicatif sur la fécondité supérieur à la durée du mariage. Il est ainsi possible d'imaginer un autre genre d'analyse où on cherche à inverser le sens des causalités, voire à trouver d'autres causalités de telle sorte que les probabilités soient conditionnées par des évènements postérieurs. Ces probabilités ne pourront être mesurées que lorsque tous les évènements auront déjà
In demographic studies and more generally in the domain of statistics, the positive sense of time is privileged. By this we mean that a conditional probability is always conditioned by events prior to the current date: marriage conditions (or used to condition) the bearing of children. Is it nonetheless unthinkable that the actions of today are partly conditioned on future events? Does a soon-to-divorce couple not have a lower probability of giving birth today? The important variable to account for is the duration separating the couple from its future divorce; and this could yield more explanatory power than the duration of the marriage. It is therefore possible to imagine another kind of analysis where one attempts to invert the direction of causality, looking to find other causalities of the sort where probabilities are conditioned of posterior events. These probabilities can be estimated only after waiting until the terminal event has occurred, thus limiting their in- 
eu lieu, ce qui limite sans doute leur utilisation mais n'exclut pas qu'on s'y intéresse tout comme un travail historique permet de mieux comprendre les mécanismes actuels.

Dans un article sur l'activité féminine Brouard [1980], nous avions calculé des probabilités conditionnées par des évènements ultérieurs 1 , et obtenu un éclairage différent sur l'évolution des reprises d'activité des femmes, en comparaison des calculs classiques 2 .

Ici nous proposons de faire un nouveau pas vers ce type d'analyse en partant des premiers fondements de l'analyse démographique qui consistent à classer les individus d'une population suivant différents critères (âge, sexe etc). Mais au lieu de prendre le critère « âge » qui est le délai qui sépare la date présente de la date de la naissance, nous prendrons le délai qui sépare la date présente de la date de la mort, intervalle qui n'a jamais reçu de nom et que nous qualifierons de 《 vie restante » ou « d'années à vivre ». En parcourant l'histoire démographique de la France depuis un siècle environ, nous verrons une autre dynamique de sa population particulièrement axée sur l'évolution de la mortalité. Dans une dernière partie nous aborderons sous cet angle nouveau les contrastes démographiques classiques qui opposent certaines régions françaises.

\section{Pyramide des années à vivre}

Si l'âge suivant le classement simple jeunesadultes-vieux, a toujours existé, l'âge chronologique fin (annuel), est un produit de la civilisation et n'est toujours pas apparu dans certaines parties du monde, particulièrement en Afrique. L'idée de classer les hommmes suivant leur âge annuel se justifie dans les premières années de la vie pour des raisons biologiques évidentes liées au développement de l'enfant ; mais pour l'âge adulte puis pour la vieillesse, les raisons administratives prennent progressivement le dessus (retraite à 65 ans)

1. Probabilité pour une femme d'être active à un certain âge sachant qu'elle sera ou ne sera pas active quelques années plus tard.

2. Probabilité pour une femme d'être active à un certain âge sachant qu'elle a été active à un âge antérieur. terest; but this limitation should not deter us from using said technique, just as historical work allows us to better understand present mechanisms.

In an article on female labor force participation Brouard [1980], we calculated probabilities conditional on later eventsi, and shed a different evolution of female activity compared with classic calculation 2 .

Here we propose to take a new step toward this kind of demographic analysis starting from the foundation of demographic analysis that consists in classifying the individuals of a population according to different criteria (age, sex, etc.). But instead of taking the criterion of age, which is the delay separating the present date from the date of birth, we will take the delay that separates the present date from the date of death, an interval that has never been named and that we call "remaining life" or "years left to live". In browsing through the demographic history of France after about a century, we will see another population dynamic of its population, particularly focused on mortality. In the final section we discuss the demographic contrasts between certain French regions under this new angle.

\section{The years-to-live pyramid}

Age classified according to the simple youngadult-old has always existed, completed chronological age (annual) is a product of civilization and has not always appeared in certain parts of the world, particularly in Africa. The idea to classify people by years of age is justified in the first years of life for evident biological reasons linked to infant development; but for adult ages and old ages, administrative reasons progressively take over (retirement at age 65).

1. The probability that a female is active at a certain age, given that she will or will not be active in selected future years

2. The probability that a female is active at a certain age, given that she was active at some earlier age 
Quelques en soient les raisons, la représentation d'une pyramide des âges annuels s'est révélée très riche en information tant pour les prévisions de toute sorte, que pour découvrir les effets de son histoire récente sur la population elle-même 3 .

Nous proposons ici de classer les individus non plus suivant l'âge mais suivant le délai qui leur reste à vivre. Si l'âge annuel n'existe toujours pas dans certaines civilisations, il semble que la vie restante, n'ait, elle, jamais existé. En effet la science ne nous permet que dans de très rares cas (le plus souvent des cas dramatiques) de prévoir la date précise de la mort d'un individu ; par contre, en l'absence de catastrophe ou d'évolution imprévue de la mortalité, il est tout à fait possible de prévoir, collectivement, les décès d'une population. Si de plus nous nous plaçons à une date déjà ancienne, au recensement de l'année 1901 par exemple, une grande partie de la popular tion de cette époque est décédée aujourd'hui (recensement de 1982) et les survivants actuels décéderont à des dates relativement bien connuest. Le classement de la population recensée en 1901 suivant la génération de décès, c'est à dire aussi suivant ce que nous appelons ici la vie restante est riche d'information.

\subsection{Le recensement de 1901}

Nous avons tout d'abord représenté sur la figure 1 la pyramide des âges (trait pointillé) de l'année 1901 qui suscite au moins deux commentaires : 1) la mortalité très importante avant un an (160\% pour les hommes et $135 \%$ pour les femmes) et nettement moindre entre 1 à 2 ans $(31 \%$ et $30 \%$ ) puis aux âges supérieurs, est la principale cause qui explique

3. Nous invitons le lecteur à se reporter à la publication Calot [1984 de la pyramide des âges annuels de la Chine obtenue à partir de son recensement de 1982, car on y découvre certes les effets de la guerre nippone mais aussi celui du bond en avant et de la révolution culturelle.

4. La mortalité aux âges élevés ne varient pas énormément et les catastrophes affectent moins les personnes âgées (les épidémies de grippe en sont pourtant un contre-exemple). Notons aussi que les seuls progrès substantiels en matière de mortalité et du point de vue démographique ne peuvent se réalisés qu'aux âges où les risques de décès sont élevés, c'est à dire aux âges élevés.
Whatever the reasons, the [graphical] representation of an annual age-pyramid reveals itself rich in information, both for all kinds of predictions and for discovering the effects of the population's own recent history on itself 3 .

We here propose classifying individuals not by age but rather by the duration of their remaining lifetime. If annual age does not exist in certain civilizations, it would appears that [the notion of] remaining lifetime has never existed. In effect science permits us in very rare cases (most often in dramatic cases) to foresee the precise date of death of an individual; In contrast, in the absence of catastrophe or unforeseen changes in mortality, it is quite possible to predict, collectively, a population's deaths. If furthermore we place ourselves at a date already in the past, at the census of 1901 for example, a large portion of the population at that time is deceased today (census of 1982), and the present survivors will die at times that are relatively well-known 1 . The classification of population censused in 1901 by death generations, that is to say according to what we call remaining lifetime, is rich in information.

\subsection{The census of 1901}

We begin by showing in Figure 1 the age pyramid (dotted line) of the year 1901 that raises two comments: 1) mortality, much more important before age 1 ( $160 \%$ o for males and $135 \%$ or for females) and clearly lower between 1 and 2 years old $(31 \%$ for males and $30 \%$ for females) and also at higher ages [through age 10], it is the main cause explain-

3. We invite the reader to refer to the reference Calot [1984] of the annual age pyramid of China obtained from the census of 1982, where one see certain effects of the war with Japan as well as the Great Leap Forward and the Cultural Revolution.

4. Mortality at high ages does not change greatly, and catastrophes affect aged persons less (influenza epidemics are a counterexample). Also note that the only substantial progress left to made concerning mortality from the demographic point of view can only be realized at ages where death risks are high, that is to say older ages. 


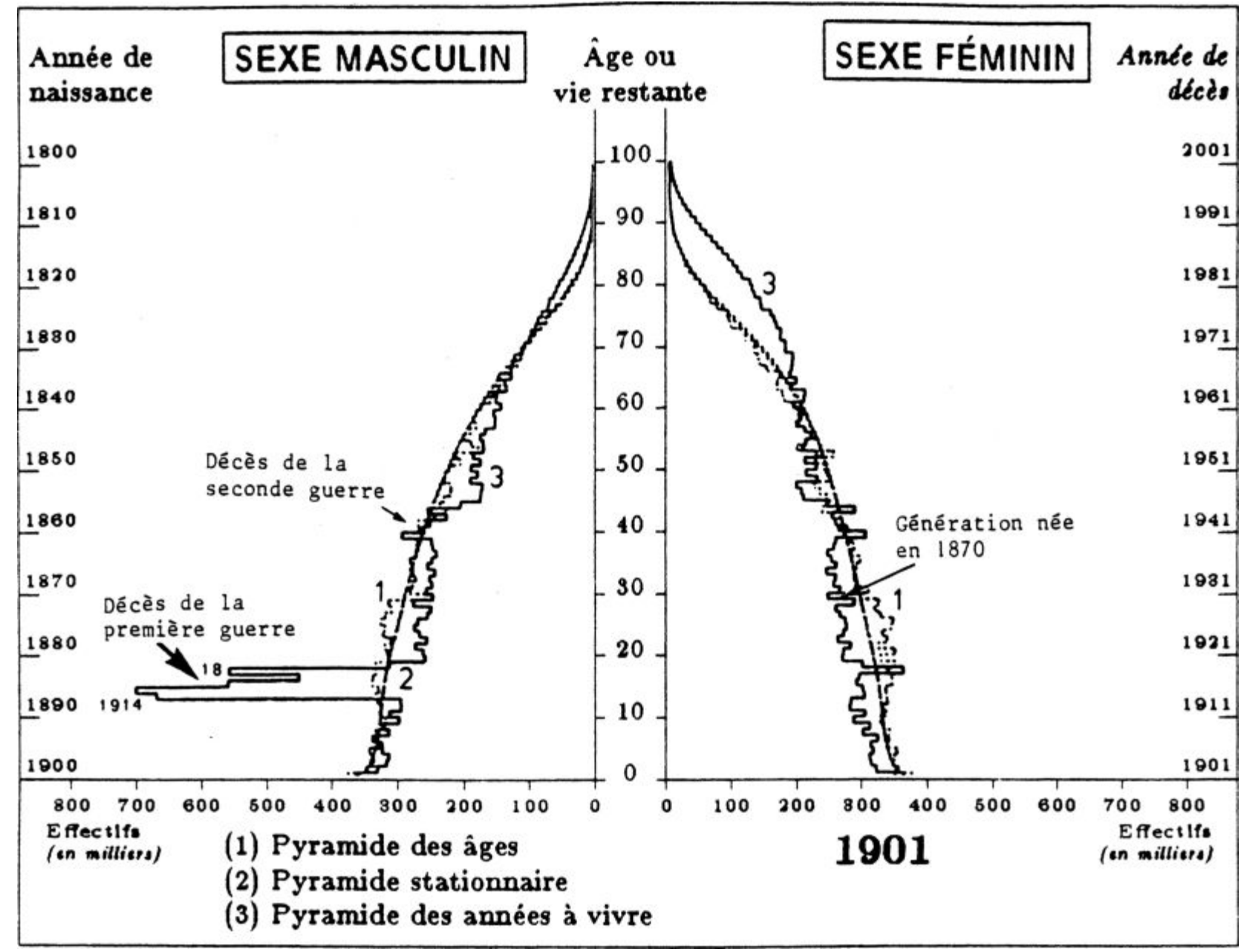

Fig. 1: Pyramide des âges, pyramide stationnaire et pyramide des années à vivre au $1^{\text {er }}$ Janvier 1901. FiG. 1: Age pyramid, stationary pyramid and remaining lifetime pyramid on $1^{\text {st }}$ January 1901.

cet évasement de la base de la pyramide. 2) la baisse de la natalité durant la guerre de 1870 est perceptible pour la génération creuse qui a 31 ans en 1901.

Hormis ce dernier à-coup et d'autres d'importance moindre non mentionnés ici, la pyramide des âges n'est pas très différente de la population stationnaire équivalente 0 représentée par une ligne en trait poin- ing the flaring at the base of the pyramid. 2) the drop in births during the war of 1870 is perceptible in the empty generation that was 31 years old in 1901.

Save for these, and those of lesser importance not mentioned here, the age pyramid is not very different from the stationary-equivalent popula-

5. C'est à dire de la pyramide des âges d'une population de taille équivalente dont :

1. la mortalité serait constante dans le temps et égale à celle observée en 1901, sur les différentes générations présentes,

2. le nombre des naissances annuel serait lui aussi constant. 
tillé gras ; ceci montre que la population française n'avait pas eu avant 1901 de catastrophe démographiques majeures, et était dans une période de transition « douce» (faible croissance).

La population stationnaire a un intérêt pour le sujet qui nous préoccupe, car dans une population rigoureusement stationnaire la pyramides des âges est aussi égale à la pyramide des années à vivre. On montre Brouard [1985] en effet que dans une population stationnaire, il y a autant d'individus ayant vécus $x$ années que d'individus ayant $x$ années à vivre.

La troisième courbe est la pyramide des années à vivre réelle, calculée en tenant compte de la mortalité effective des générations. Si la base d'une telle pyramide exprime des effectifs, l'axe vertical est doublement gradué non plus suivant l'âge et la génération de naissance, mais selon les années restant à vivre et la génération de décès. C'est en effet aussi l'échéancier des décès de la population présente en 1901, tous âges confondus.

Le phénomène le plus visible résulte bien entendu des pertes de la guerre de 1914-18 qui atteignent un maximum durant l'année 1915. Notons que ces réultats résultent de calculs effectués à partir des estimation de la population et des décès par âge durant les guerres de J. Vallin Vallin [1973] 6. L'année 1918 est plus meutrière que les années encadrantes en raison d'une épidémie de grippe durant l'hiver 1918-19, qu'ou remarque du côté féminin, alors que la guerre elle-même ne fait pas de victime parmi la population féminine. L'importance relative des décès de l'année 1919 résulte de cette même grippe mais aussi de décès des grands blessés. Ce regroupement tragique des décès a pour conséquence un déficit pour les années (de vie restante) suivantes.

6. Mentionnons pour comprendre les difficultés auxquelles s'est heurté J. Vallin, que les deux recensements encadrants par exemple, la guerre de 1914-18, sont ceux de 1911 et de 1921, et que les données sur les décès provenant de l'état-civil ne concernent que 77 départements et encore uniquement des décès de civils. L'estimation repose sur d'autres sources donnant une évaluation des pertes de guerre mais surtout par différence entre la population attendue en 1921 et la population estimé par le recensement. Les migrations composées surtout d'Italiens compliquent les évaluations. tion 0 shown with the thick dashed line; this shows that the French population did not have any major demographic catastrophes before 1901, and was in a "soft" period of transition (weak growth).

The stationary population is of interest for the present subject because in a rigorously stationary population the age pyramid is also equal to the years-left pyramid. We show Brouard [1985] in effect that in a stationary population, there are the same number of individuals having lived $x$ years as there are individuals having $x$ years left to live [A proof of this theorem from the cited reference is reproduced in the Appendix].

The third curve is the real years-left pyramid, calculated taking into account the observed mortality of each generation. If the base of this pyramid is expressed in counts [thousands], the vertical axis is a double scale, not only having age and birth cohort, but also have years left and death cohort. It is in effect the [annual] death schedule of the population present in 1901, all ages taken together.

The most visible phenomenon of course results from the losses of the war of 1914-1918 that reached a maximum during the year 1915 . Note that these results come from estimates of population and deaths by age during the war years estimated by Vallin Vallin [1973] 6. The year 1918 is deadlier than the surrounding years due to an influenza epidemic during the winter of 1918-1919;

5. That is to say the age pyramid of a population of the same size where:

1. mortality is constant over time and equal to that observed in 1901, over the different generations present;

2 . the annual number of births is also constant.

6 . We mention, to understand the difficulties surmounted by J. Vallin, that the two censuses bracketing the war of 1914-1918 are from 1911 and 1921, and that vital statistics death count data refer to deaths registered in only 77 departments of France [incomplete coverage] and within the civil population only.

His estimates rely on other sources permitting an evaluation of war losses, but also by estimating the differences between the expected population in 1921 with the observed populations during the 1921 census. Migrations, composed mainly of Italians, complicate the evaluation. 
Notons aussi qu'en raison de la baisse de la mortalité au cours du siècle, la répartition selon la vie restante des survivants de la première guerre, ne doit pas être parallèle $\mathrm{U}$ à celle donnée par la pyramide stationnaire mais plus étirée. C'est en effet ce que nous commencions à observer mais la seconde guerre intervient et anticipe des décès sur une très courte période. On aura alors remarqué qu'en définitive et pour les hommes, la baisse de la mortalité a tout juste compensé les lourdes pertes des deux guerres, et qu'ainsi la proportion de la population de 1901 qui aura survé$\mathrm{cu}$, par exemple, 70 ans, c'est à dire vécu au delà des années 1970, est pratiquement identique à la proportion de la population âgée de plus de 70 ans en 1901. Pour les femmes, la baisse de la mortalité l'emporte largement.

La base de la pyramide des années à vivre est tout aussi évasée que la pyramide des âges ou stationnaire, en raison du même phénomène : en effet, en plus des décès «normaux » s'ajoute un surcroît de décès d'enfants de moins d'un an.

Les décès dûs à la seconde guerre sont perceptibles sur cette figure, mais le sont encore plus si nous nous plaçons par exemple aux recensements de 1921 ou de 1931.

\subsection{La population au recensement de 1921}

Nous remarquons sur la figure 2 que la seconde guerre a fait beaucoup de victimes parmi la population féminine contrairement à la première. Pour les hommes, les pertes durant l'année 1940 (décès de militaires) sont plus importantes que durant l'année 1944 (décès pendant la résistance, durant la libération ou en déportation) ; c'est l'inverse pour les femmes.

$\mathrm{Si}$ on examine maintenant la pyramide des âges, l'absence longue des hommes mobilisés pendant les années de guerre, se traduit par le classique déficit des classes creuses. Les pertes masculines de la guerre de 1914 sont nettement visibles sur la pyramide des âges de l'année 1921, mais les décès sont répartis sur un nombre élevé de classes d'âge (de 20 à 45 ans environ).

7. En mathématique nous dirions affine. this phenomena can be seen on the female side of the years-left pyramid while the war itself did not make victims of [have a direct mortality impact on] the female population. The relative importance of deaths in the year 1919 is due to this same influenza epidemic but also to the deaths of the severely wounded. This tragic harvesting of deaths results in a deficit in the following years (of remaining life) [in the years-left pyramid].

Note that due to the decrease in mortality over the course of the century, the redistribution by remaining years of life of the survivors of World War I is not parallel 7 to the stationary pyramid but more stretched. In fact, we started observing this [stretching effect], but World War II occurred and precipitated deaths over a very short period. In summary, we can remark that definitely for males, the [postwar] decrease in mortality just barely compensated the heavy losses from the two wars, and as a consequence the proportion of the 1901 population that would have survived, for example, to at least age 70 , i.e., lived into the 1970s, is practically identical to the elderly proportion of 70 or more years in 1901. For females, the decrease in mortality brought large winnings [to the top of the years-left pyramid].

The base of the years-to-live pyramid is also flared like the stationary age pyramid, due to the same phenomenon: in effect, aside from "normal deaths", we add in the deaths of infants under 1 year of age.

Deaths from the Second World War are visible in this figure, but even more so if we place ourselves for instance at the censuses of 1921 or 1931.

\subsection{The population at the census of 1921}

We remark on Figure 2 that World War II made many victims of the female population, unlike World War I. For males, losses during the year

7. In mathematics, we use the term "affine". 


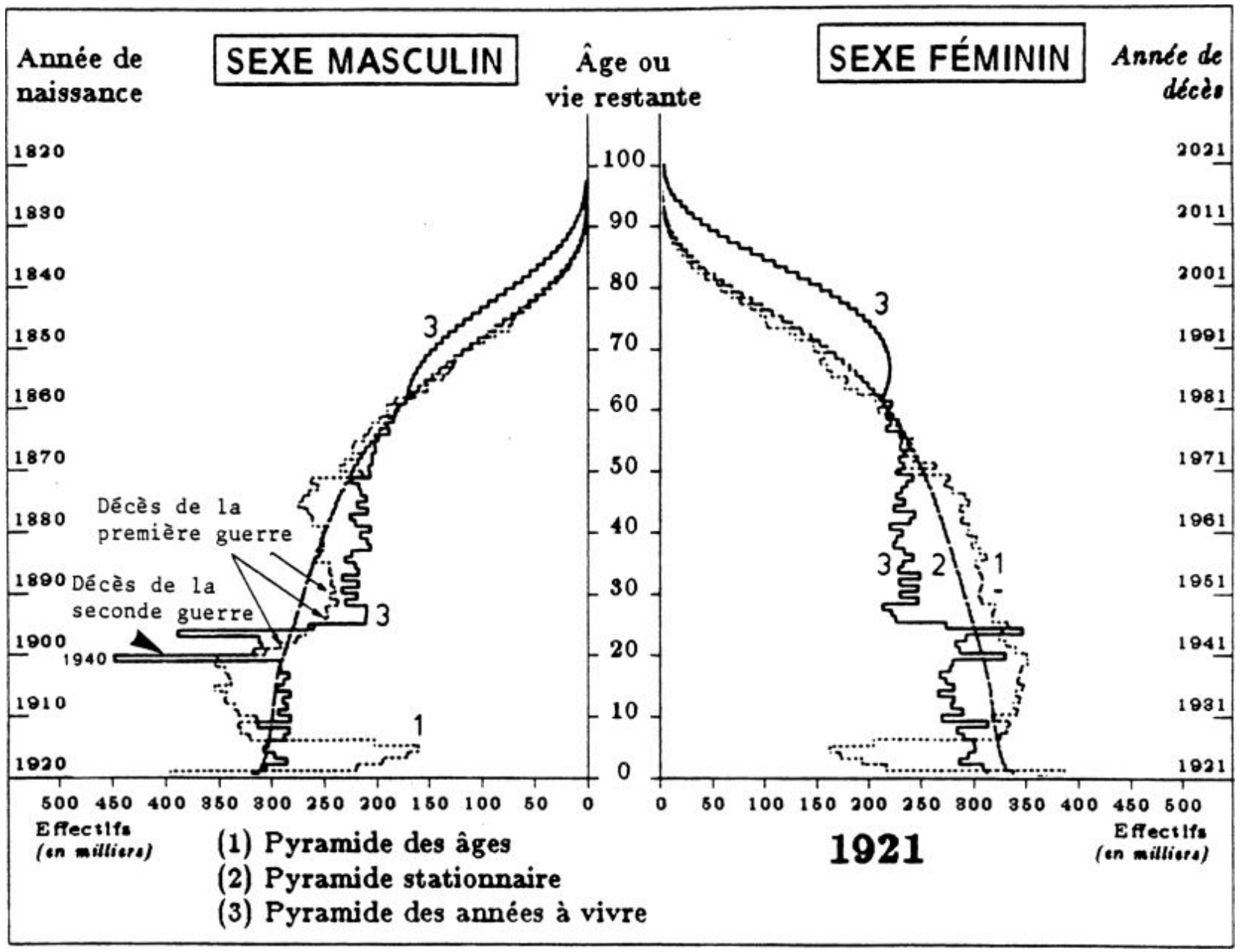

FIG. 2: Pyramide des âges, pyramide stationnaire et pyramide des années à vivre au $1^{\mathrm{er}}$ janvier 1921. FIG. 2: Age pyramid, stationary pyramid and remaining lifetime pyramid on $1^{\text {st }}$ January 1921.

Au contraire, sur la pyramide des années à vivre, les décès de guerre (ceux de la suivante) sont concentrés, alors que l'effet des classes creuses (dues à la guerre passée) est très dilué.

La pyramide des années à vivre est en effet beaucoup plus sensible à une perturbation de la pyramide des âges aux âges élevés qu'aux jeunes âges. Fort de cette remarque, nous comprenons pourquoi, durant les premières années, la pyramide des années à vivre suit la pyramide stationnaire du côté masculin mais reste en deçà du côté féminin. Aux âges élevés (supérieurs à 60 ans) la pyramide des âges et la pyramide
1940 (military deaths) were greater than during the year 1944 (deaths during the Resistance, Liberation, or in deportation); It is the inverse case for females [1944 was worse for females than 1940].

If one now examines the age pyramid, the long absence of males mobilized during the war years translates to the classic "classes creuses" [small cohort sizes]. Male losses from 1914 are clearly visible in the 1921 age pyramid, but the deaths are spread over a large number of age classes (from about age 20 to 45). To the contrary, in the yearsto-live pyramid, the war deaths (those of the Sec- 
stationnaire de sexe masculin coïncident, alors que du côté féminin la pyramide des âges se situe légèrement en dessous de la pyramide stationnaire.

Fluctuations conjoncturelles de la mortalité Nous pouvons remarquer qu'au delà de 60 années de vie restante, la pyramide des années à vivre est lisse. En effet, nos données les plus récentes sur la mortalité s'arrêtent à l'année 1982, et nous avons dû supposer (hypothèse minimimale) que la mortalité future serait identique à celle de l'année 1982. Cette partie de la pyramide est donc sans doute trop compacte et devrait être plus étirée si la mortalité continue à baisser comme elle le fait actuellement, mais elle est surtout soustraite aux fluctuations conjoncturelles de la mortalité, fluctuations que l'on remarque sur cette même figure avant 60 ans. Les fluctuations conjoncturelles de la mortalité sont du même ordre si ce n'est d'un ordre supérieur (en dehors des guerres bien évidemment) à celles de la natalité. Ces fluctuations qui résultent au début du siècle essentiellement - des épidémies de grippe se sont estompées durant les dernières décades.

Plus on se rapproche des recensements récents, plus la partie extrapolée de la pyramide des années à vivre devient importante ; la pyramide des années à vivre de l'année 1982 sera alors entièrement extrapolée, mais examinons maintenant la population aux recensements de 1946 et de 1962.

\subsection{Les recensements de 1946 et de 1962}

Le recensement de 1946 (figure 3) présente une situation démographique assez particulière puisque d'une part les générations masculines peu nombreuses puisque touchées par la première guerre atteignent des âges plus élevés (entre 60 et 70 ans), et que d'autre part la faible natalité d'avant la seconde guerre et durant la guerre elle-même a pour conséquence les faibles effectifs des jeunes générations. Cette situation, - - peu d'enfants, moins de vieux - qui coïncide avec l'instauration de la Sécurité Sociale, va être vite bouleversée par le baby-boom. La situation démographique lors du recensement de 1962 (figure 4) offre en effet des perspectives différentes puisque nous nous trouvons avec ond) are concentrated, while the effects of the "classes creuses" (due to the previous war) are very diluted.

The years-to-live pyramid is in effect much more sensitive to perturbations of the age pyramid in older ages than in young ages. Based on this notion, we understand why in the first years of life the years-to-live pyramid follows the corresponding stationary male pyramid, whereas on the female side the years-to-live pyramid is situated inside of the stationary pyramid. In old ages (ages above 60) the male stationary and age pyramids coincide, whereas on the female side the age pyramid falls slightly below the stationary pyramid.

Period mortality fluctuations We can note that above 60 years of remaining life, the yearsto-live pyramid is smooth. This is an artifact because our most recent mortality data are those of the year 1982, and we must assume (minimal hypothesis) that future mortality will be identical to that of the year 1982. This part of the pyramid is therefore doubtless too compact and should be more stretched if mortality continues falling as it is currently [in 1982], but above all it lacks the period fluctuations of mortality that can be seen in the same figure below 60 remaining years of life. Period fluctuations in mortality are of the same order of magnitude if not greater than (outside wars quite evidently) those of births. These fluctuations result, at the start of the century essentially, from influenza epidemics were erased in latter decades.

The closer one approaches to recent censuses, the greater is the extrapolated portion of the years-to-live pyramid; the years-to-live pyramid of the year 1982 is therefore entirely extrapolated, but we examine now the censuses of 1946 and 1962.

\subsection{The censuses of 1946 and 1962}

The census of 1946 (Figure 3) presents a rather special demographic situation, since on the one 


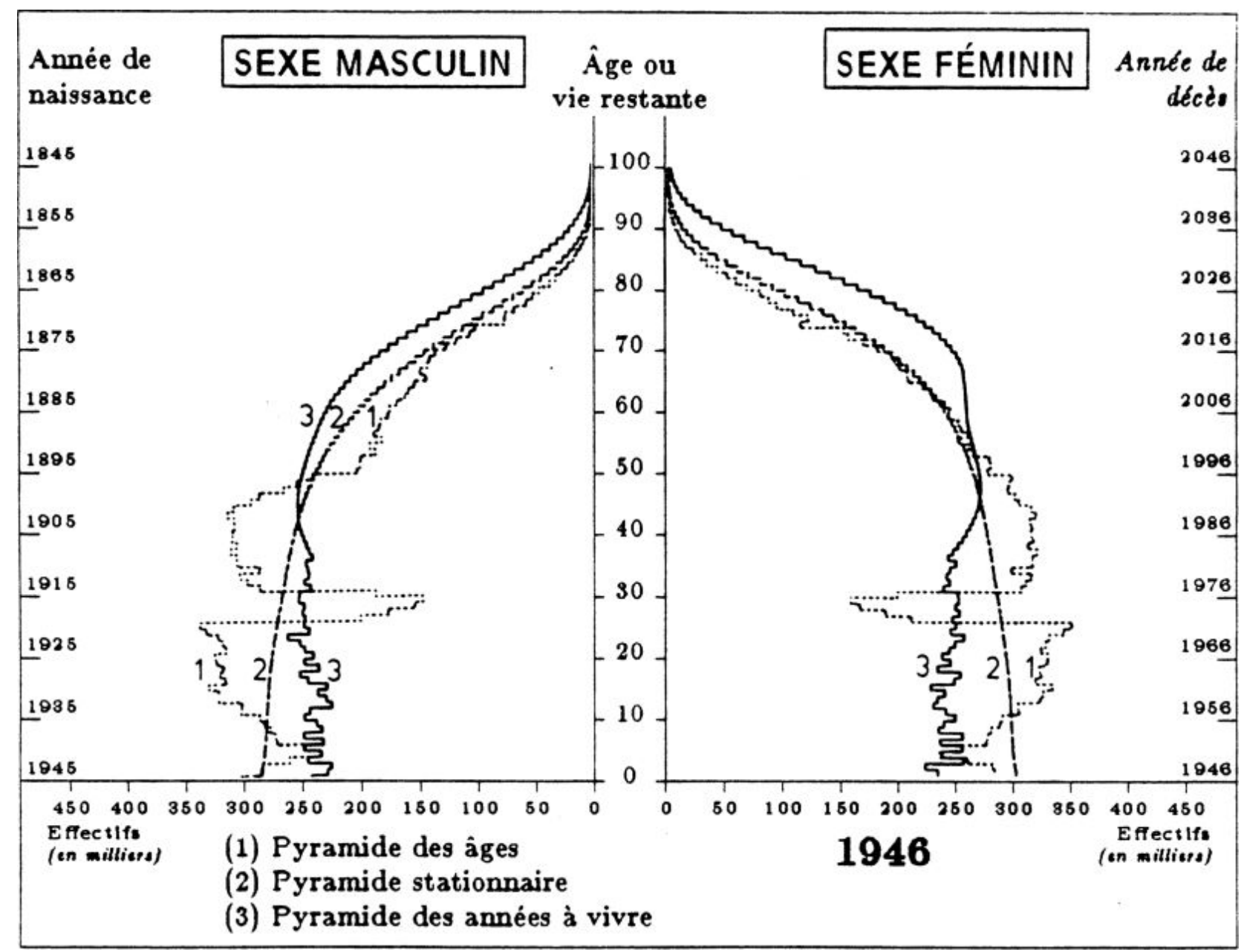

Fig. 3: Pyramide des âges, pyramide stationnaire et pyramide des années à vivre au $1^{\mathrm{er}}$ janvier 1946. FIG. 3: Age pyramid, stationary pyramid and remaining lifetime pyramid on $1^{\text {st }}$ January 1946.

16 générations de classes nombreuses (plus de 800000 nouveaux-nés chacune). L'effectif des individus d'âge actif n'a pas beaucoup évolué puisque les générations creuses sont encore d'âge actif (42-47 ans). La population masculine à la retraite est relativement moins nombreuse.

Ces variations de structure de la pyramide des âges ont souvent été décrites dans la littérature, voyons comment elles se traduisent en terme de vie restante. On remarque tout d'abord qu'à chacune des deux dates 1946 et 1962, la population est beaucoup plus jeune que celle décrite par la population stationnaire. hand male cohorts having survived World War I are few to reach high ages (between 45 and 70 $[20+25$ and $45+25])$, and on the other hand low natality before and during World War II results in small stocks in young generations [at the base of the age pyramid]. This situation, few children and fewer elderly, which coincided with the establishment of Social Security, was quickly overwhelmed by the baby-boom. The demographic situation at the census of 1962 (Figure 4) indeed presents an unusual perspective since we find ourselves with 16 large generations (over 800,000 new- 


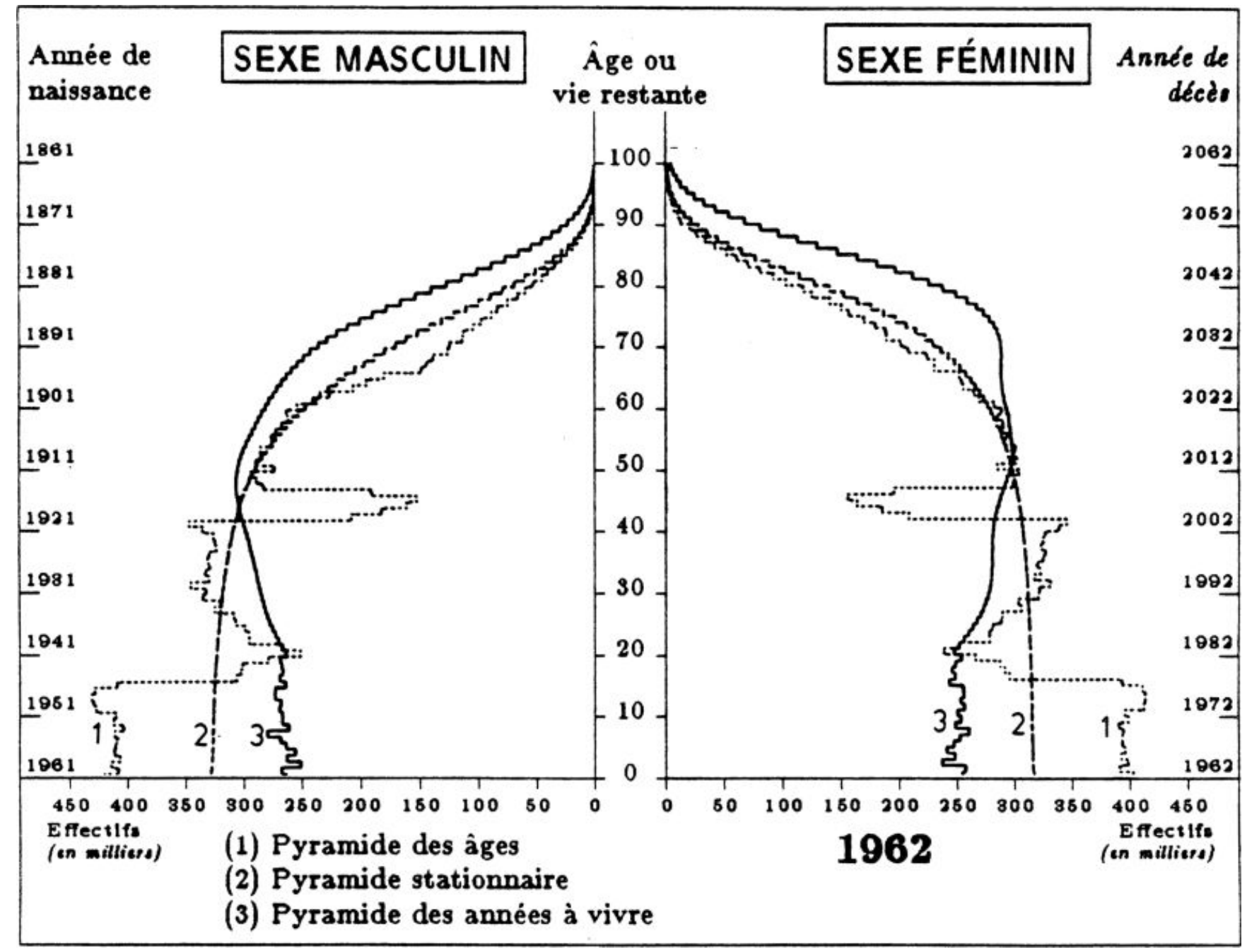

FIG. 4 : Pyramide des âges, pyramide stationnaire et pyramide des années à vivre au $1^{\text {er }}$ Janvier 1962. FIG. 4: Age pyramid, stationary pyramid and remaining lifetime pyramid on $1^{\text {st }}$ January 1962. 
La pyramide des années à vivre est très sensible à ce déséquilibre et prend une forme bombée vers le haut caractéristique d'une population dont le potentiel de vie future est largement supérieur à la vie vécue. La durée de vie moyenne ultérieure (moyenne des durées de vie restante) est de 42,6 ans en 1962 alors que l'âge moyen de la population est 34,9 ans. L'indice défini comme le rapport des durées moyennes passe de 115 en 1946 à 122 en 1962.

Ici l'intérêt de la pyramide des années à vivre est de lisser les à-coups de la pyramide des âges et de faire apparaître l'effet de deux phénomènes, allant dans le même sens, qui sont l'allongement de la vie due à la baisse de la mortalité et la forte natalité des 15 dernières années.

Les dernières données dont nous disposons sont celles du recensement de 1982.

\subsection{Le recensement de 1982}

Nous remarquons sur la figure 5 que la tendance observée auparavant s'est maintenue. L'âge moyen restant à vivre (42,3 ans) est de nouveau largement supérieur à l'âge moyen de la population (35,9 ans), et l'indice atteint la valeur (118). Il convient de s'interroger sur la signification d'un tel indice. Laissons de côté les préoccupations liées à la natalité et à la fécondité future et intéressons nous seulement à la mortalité et à son lien avec la structure par âge de la population.

Il est clair que puisque la mortalité a fortement évolué depuis le début du siècle, la proportion des personnes âgées est bien inférieure en 1982 à celle vers laquelle la mortalité actuelle nous conduit. Si ce phénomène est assez difficile à voir en comparant la pyramide des âges à la pyramide stationnaire, il est flagrant si on compare cette même pyramide à la pyrar mide des années à vivre calculée avec la mortalité transversale de l'année 1982. Et, plus nous appliquerons à la pyramide des âges actuelle des risques de décès faibles, plus la distorsion entre les trois pyramides sera grande. A l'inverse, on pourrait appliquer une mortalité plus grande de façon à faire pratiquement coïncider les trois pyramides. borns each). The stock of people in active ages had not changed much since the "classes creuses" were still in active ages (aged 42-47). The retired male population is relatively less numerous.

The above variations in the age pyramid structure have often been described in the literature; let us see how they translate in terms of remaining lifetime. At first we note that at both 1946 and 1962 , the population is much younger than that implied by the stationary population. The yearsleft pyramid is very sensitive to this imbalance and assumes a top-heavy form, the characteristic of a population in which the potential for future life is far greater than life lived. The subsequent mean duration of life left (mean of remaining years of life) was 42.6 years in 1962 , while the mean age of the population was 34.9 years. The index defined as the ratio of the mean durations [years left to years lived] increased from 115 in 1946 to 122 in 1962.

Here the value of the years-left pyramid is to smooth the noise of the age pyramid and to make apparent the effect of two phenomena going in the same direction, which are the lengthening of life due to decreases in mortality and the strong fertility of the last 15 years.

The most recent available data that we dispose of are those of the 1982 census.

\subsection{The census of 1982}

We note about figure 5 that the trends observed earlier are maintained. The mean remaining lifespan (42.3 years) is again much greater than the mean age of the population (35.9 years), with the index reaching a value of 118 . Let us consider the meaning of this index. Setting aside concerns related to future births and fertility, let us focus only on mortality and its link with the population age structure.

It is clear, since mortality changed so strongly since the start of the century, that the proportion of elderly persons is much lower in 1982 than that to which the current mortality conditions are 


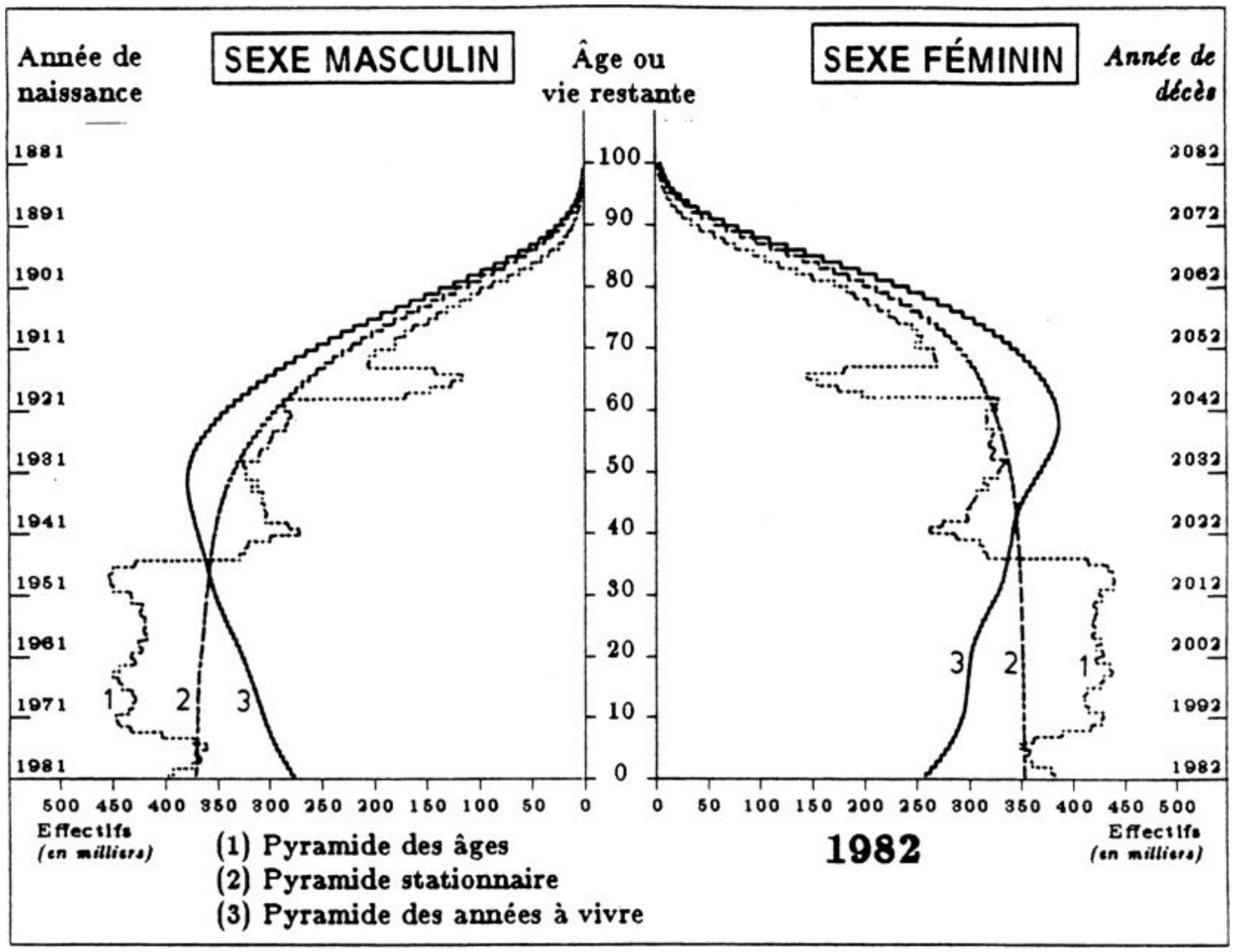

FIG. 5 : Pyramide des âges, pyramide stationnaire et pyramide des années à vivre au $1^{\mathrm{er}}$ janvier 1982. FIG. 5: Age pyramid, stationary pyramid and remaining lifetime pyramid on $1^{\text {st }}$ January 1982.

Essayons maintenant d'isoler le facteur mortalité, parmi les autres facteurs (natalité, fécondité, migrations) qui ont conduit à la structure actuelle de la population.

\subsection{Proportions de survivants des généra- tions et fonction de survie du moment}

En 1982 l'espérance de vie, qui est la taille de la population stationnaire équivalente divisée par le nombre annuel des naissances, ou encore l'aire de la fonction de survie du moment (70,3 ans pour les hommes et 78,5 ans pour les femmes) représentée steering us. If this phenomenon is rather difficult to see in comparing the age and stationary pyramids, it is obvious if we compare with the years-tolive pyramid calculated with the period mortality of 1982 . Were we to apply lower death rates to the current age-pyramid, the distortion between the three pyramids would be even greater. Inversely, one could apply greater mortality, such that the three pyramids practically coincide.

We now attempt to isolate mortality effects, among the other factors (natality, fertility, migration) that have driven the present [in 1982] popu- 


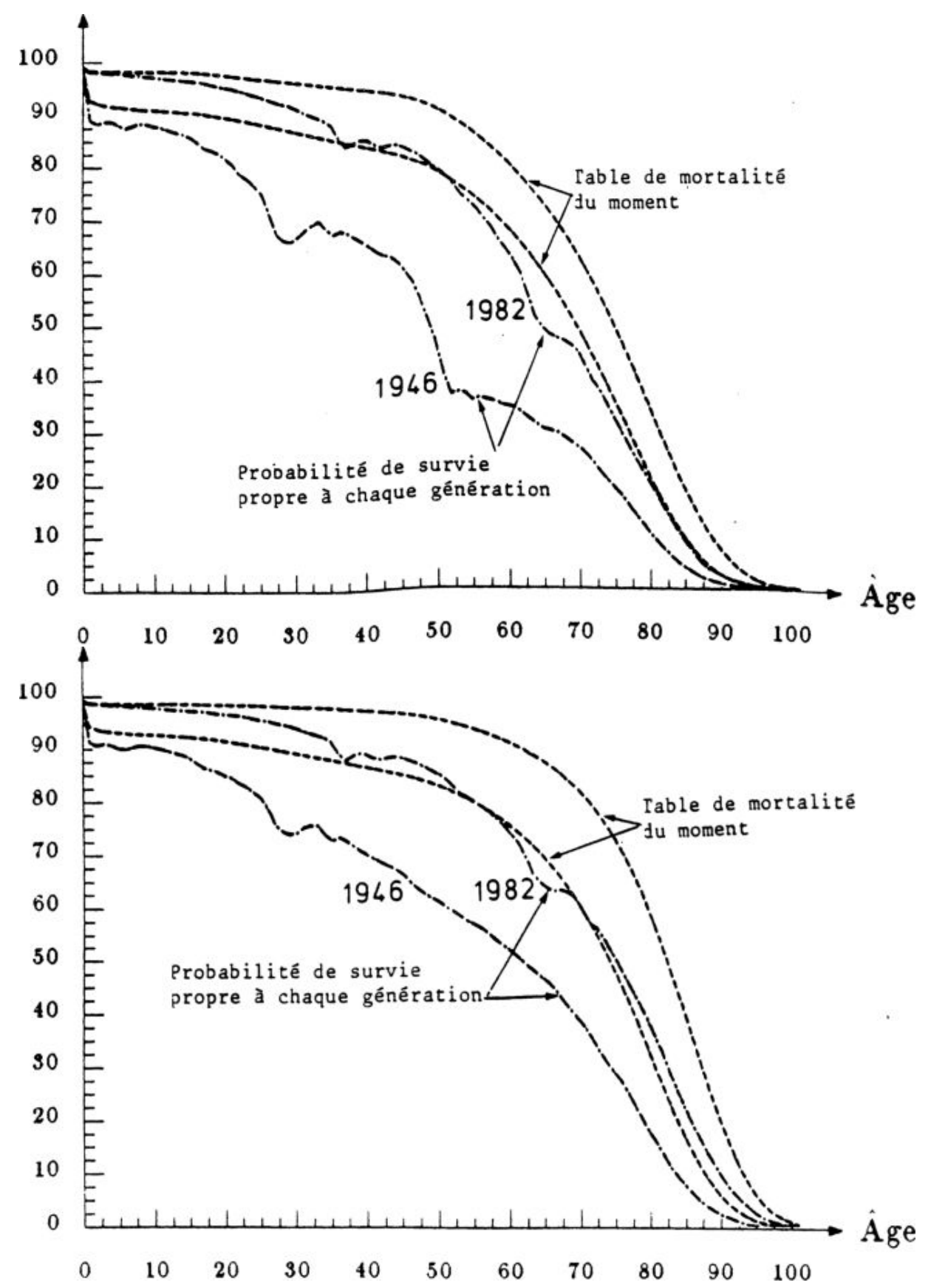

Fig. 6 : Fonctions de survie déduite d'une table de mortalité du moment et proportions de survivant appartenant à différentes générations. —-1946 et 1982-

FIG. 6: Survival function of the period life table and proportions of survivors from each cohorts. -1946 and $1982-$ 
sur la figure 6, surestime beaucoup — plus de 20 ans 8 - la durée de vie réelle moyenne des générations nées il y a 80 ans, et sous-estime la durée de vie probable moyenne des nouveaux-nés de l'année 1982 (sans doute nettement moins, puisque la mortalité infantile, réduite aujourd'hui à moins de $8 \%$, ne peut plus baisser en variation absolue importante, et qu'il faudrait une baisse aux âges élevés importante). On peut alors se demander quelle est la courbe de survie qui tient compte de la mortalité passée pour les générations anciennes, et de la mortalité récente pour les nouvelles générations. Cette fonction de survie est donnée par la proportion de survivants en 1982 des différentes générations présentes en 19829 (elle sera notée PSG, comme Proportion de Survivants des Générations, par la suite). L'aire (61,8 ans pour les hommes et 68,9 pour les femmes en 1982) représente (voir la figure 6) alors la durée de vie moyenne actuelle compte-tenu de l'histoire passée de la mortalité, histoire plus ou moins longue suivant les générations. La figure 6 représente à la fois la fonction de survie (courbe sans heurt) déduite de la mortalité du moment et la fonction de survie PSG; nous avons ajouté les courbes relatives à l'année 1946 comme élément de comparaison. Evidemment, les fonctions du type PSG ne sont pas forcément décroissantes et ce sont aussi ses fluctuations qui nous intéressent. On remarque en effet différentes cassures ou remontées importantes qu'il convient de décrire.

Les deux premières fluctuations observées sur la courbe de 1946 à 2-6 ans puis 26-34 ans se retrouvent à 36-40 ans et 62-70 ans en 1982. Elles résultent d'une hausse de la mortalité infantile durant les guerres qui, en ce qui concerne la seconde guerre s'est prolongée durant l'année 1945⒑

La troisième fluctuation ne concerne que la courbe maculine de 1946 et a pour cause les décès de la guerre

8. La durée de vie moyenne de la génération née en 1899 est estimée à 48 ans pour les hommes et 55 ans pour les femmes.

9. Ou probabilité de survie depuis la naissance jusqu'en 1982.

10. On explique cette hausse relative par une désorganisation des systèmes de santé en raison non seulement de la guerre mais aussi de l'afHux du nombre élevé des naissances durant l'année 1946 (début du baby-boom), qui perturbe la génération 1945. lation structure.

\subsection{Cohort survivorship and the period survival function}

In 1982 life expectancy, which is the ratio of the stationary equivalent population to annual number of births, or the area beneath the period survival function (70.3 years for males and 78.5 years for females) shown in figure 6 greatly overestimates - by more than 20 years 8 - the real mean lifespan of the cohorts born 80 years ago, and underestimates the mean lifespan of babies born in 1982; surely significantly so, since infant mortality, today as low as $8 \%$, can no longer decrease in absolute variation, and there should be large decreases in old age mortality. One can then ask what is the survival curve that takes into account past cohort mortality of older generations, and the recent mortality of new cohorts? This survival function is given by the proportion surviving in 1982 of each of the different cohorts present in 1982 (we denote this as CPS, the Cohort Proportion Surviving in the following [PSG in the original, elsewhere in the English literature this is now called CAL, for Cohort Adjusted Life]). The area (61.8 years for males and 68.9 for females in 1982) gives (see figure 6) the current mean lifespan, taking into account the past mortality history, whose duration depends on the age of the cohorts. Figure 6 shows both the survival function (smooth curve) derived from period mortality and the CPS function; we include the curves relative to the year 1946 for the sake of comparison. Evidently, CPS functions are not strictly declining functions, and their fluctuations are of interest. We point out various noteworthy rises and falls.

The first two fluctuations observed in the 1946 curve at ages 2-6 and 26-34 appear again in 1982 at ages $36-40$ and $62-70$. These result from an increase in infant mortality during the war

8. The average length of life for the 1899 birth cohort is estimated at 48 years for males and 55 years for females.

9. The probability of surviving from birth up to 1982 . 
de 1914-1918 : l'écart global entre cette courbe PSG et la fonction de survie du moment est impressionnant (46,4 années contre 61,1 pour les hommes et 53,9 contre 66,2 pour les femmes).

L'écart global entre les courbes (PSG et survie du moment) de l'année 1946 et celles de 1982 résultent du fait que la mortalité infantile est encore très importante en 1946 (78\%o) ; elle ne baisse réellement qu'après les années 50.

Voyons maintenant le lien entre la fonction PSG et la structure par âge réelle d'une population.

\subsection{Vieillisement et pyramide des âges}

Transformons cette fonction de survie (PSG) en pyramide des âges, en faisant le raisonnement équivalent à celui que l'on fait pour la population stationnaire; supposons que le nombre annuel des naissances ait été constant depuis toujours, mais que la mortalité fût celle observée réellement depuis plus de 100 ans ; alors la pyramide actuelle aurait la forme de cette fonction de survie PSG 11 (voir la figure 7).

La confrontation de ces pyramides PSG, ramenées à l'échelle de 40,1 millions d'habitants en 1946 et de 54,3 en 1982, avec les pyramides des âges réelles, nous montre la part due à la mortalité et à son évolution dans les échancrures observées sur une pyramide des âges. Les différences qui subsistent résultent essentiellemnt des variations de la natalité. En 1946 le manque de naissance avant et pendant la guerre crée un déséquilibre flagrant (l'âge moyen de la pyramide PSG est de 32,2 ans contre 35,6 pour la pyramide des âges), mais la forte natalité de 1946 à 1962 environ va compenser ce déficit, et la situation de 1982 est plus équilibrée $(35,82$ ans pour la PSG et 35,86 pour la pyramide des âges).

Nous avons introduit dans cet article deux types de pyramide : la pyramide des années à vivre, et la pyramide donnant les proportions de survivant de chaque génération (PSG). Il convient de revenir sur leurs différences :

11. les trapèzes des fonctions de survie ont été transformés en carrés, conformément aux représentations classiques des pyramides des âges. years, which for the Second World War extended through the year 194510.

The third fluctuation concerns the male curve of 1946 and is due to the deaths from the war of 1914-1918: the global gap between this CPS curve and the period survival function is impressive (46.4 years compared with 61.1 for males and 53.9 versus 66.2 for females).

The global gap between the curves (CPS and period survival) of the year 1946 and 1982 is due to the fact that infant mortality was still very high in $1946(78 \%$ o); it really started to drop only after the $1950 \mathrm{~s}$.

We now see the link between the CPS function and the real age structure of a population.

\subsection{Ageing and the age pyramid}

We transform this survival function (CPS) into an age pyramid using the same reasoning as that done for the stationary population.; assume that the annual number of births has been constant for a long time, but that mortality was that actually observed over more than 100 years; then the current pyramid would take the shape of CPS 11 (see Figure (7).

The comparison between the CPS pyramids, brought to scale of 40.1 million inhabitants in 1946 and 54.3 in 1982 alongside the observed age pyramids, shows us the notches observed in the age pyramid that are due to mortality. The differences that remain [in the age pyramid] are due essentially to variations in natality. In 1946 the birth dearth during and prior to the war creates an obvious imbalance (the mean age of the CPS pyramid is 32.2 years compared with 35.6 years in the age pyramid), but the strong natality from 1946 to around 1962 compensated this deficit, and the

10. This relative increase is explained by the dismantling of the health system due not only to the war but also to the surge in the number of births during 1946 (the debut of the baby-boom), that perturbed the 1945 cohort.

11. The parallelograms from the survival function have been transformed into squares, in keeping with the classic representation of the age pyramid 


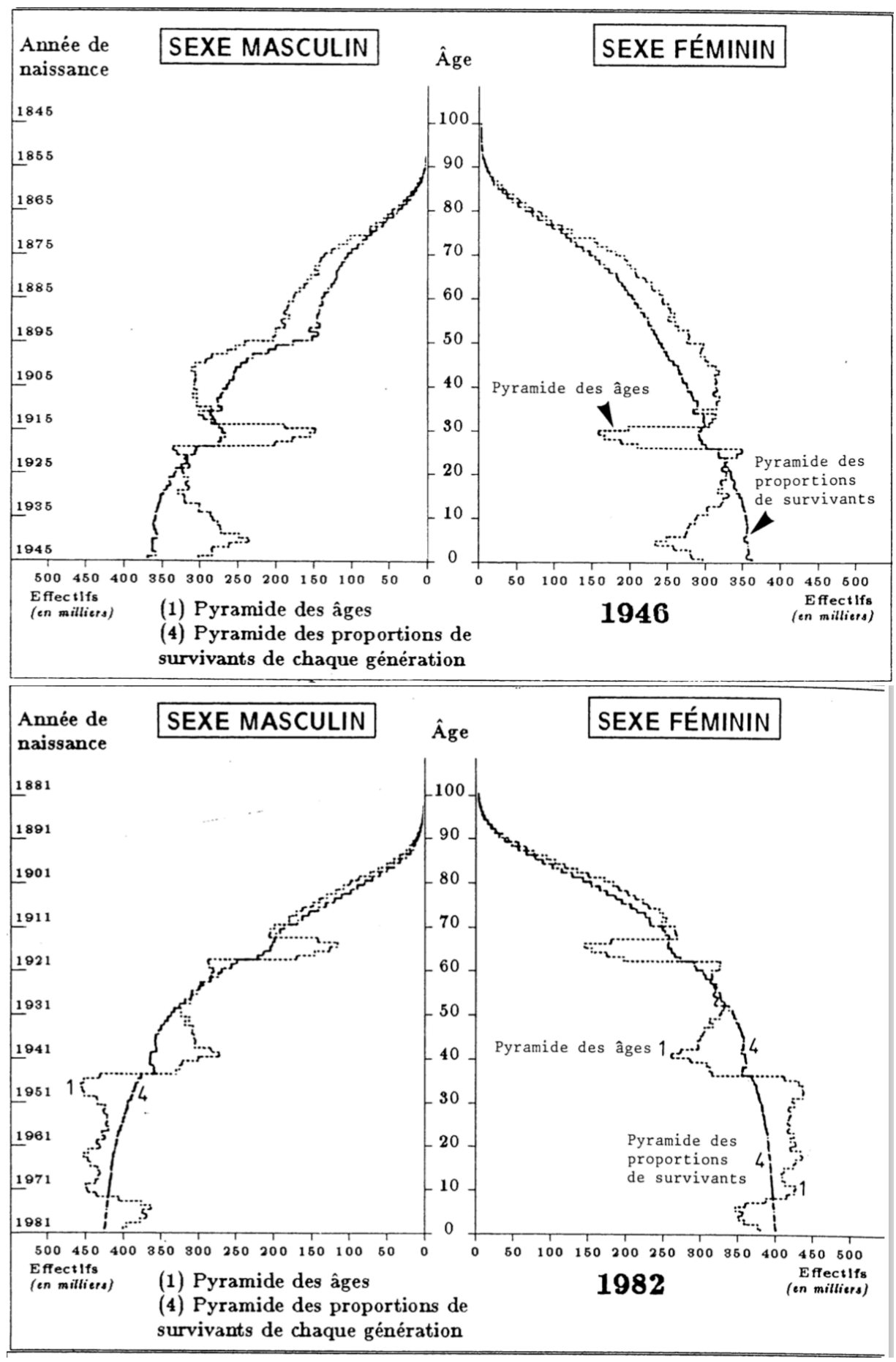

FIG. 7 : Comparaison de la pyramide des âges au $1^{\mathrm{er}}$ janvier 1982 à celle qu'on aurait obtenu si le nombre des naissances n'avait jamais varié (idem pour l'année 1946).

FIG. 7: Comparison of the age pyramid on 1st January 1982 to the fictitious age pyramid that would have been obtained if the number of births never changed (idem for year 1946). 
La pyramide des proportions de survivants propres à chaque génération, est un outil qui permet en créant une population fictive, d'étudier la structure par âge d'une population en considérant sa mortalité passée comme des données exogènes.

Une pyramide des années à vivre décrit la situation démographique d'une population sous un autre angle. Elle classe la population réelle en sous-populations homogènes du point [de vue] de leur survie.

Dans le cas où la pyramide des âges est relativement en équilibre par rapport à la pyramide PSG (cas de l'année 1982), le déséquilibre de la pyramide des annéees à vivre traduit alors le vieillissement dû à la mortalité plus faible, à âge égal, des jeunes générations comparée à celle des plus âgées.

Nous nous sommes surtout intéressé jusqu'à maintenant aux déséquilibres globaux entre les classes d'âge, mais la pyramide des années à vivre de l'année 1982 indique que le déséquilibre entre les effectifs masculins et féminins prend une ampleur toute nouvelle. Le fait que les hommes vivent moins longtemps que les femmes n'est pas nouveau, mais l'accroissement de l'écart est lui plus récent. Le rapport entre la durée de vie restante moyenne de la population féminine et celle de la population masculine atteint $\frac{44.1}{40.2} \times 100=110$.

Contrairement aux projections démographiques qui doivent faire des hypothèses hasardeuses sur l'évolution de la fécondité, les pyramides des années à vivre ne font d'hypothèses que sur la mortalité, qui est, sauf catastrophe, beaucoup plus stable dans son évolution. Elles ne servent pas aux mêmes buts mais permettent de prendre conscience des mêmes phénomènes sous un angle différent et donc plus complètement.

On pourrait par exemple faire des hypothèses sur l'évolution de l'âge à la prise de retraite, des divorces, etc., et décomposer la pyramide des années à vivre en population active et inactive, mariée, veuve ou divorcée etc, et obtenir un éclairage nouveau.

Nous allons voir maintenant comment les déséquilibres de structure observés sur la France entière sont souvent aggravés au niveu régional. situation in 1982 is more balanced (35.82 for the CPS and 35.86 for the age pyramid).

We have introduced in this article two kinds of pyramids: the years-to-live pyramid and the pyramid giving the proportion surviving from each cohort (CPS). We should review their differences:

The pyramid of the proportion surviving from each cohort is a tool that permits, by creating a fictitious population, studying the age structure of a population while considering its mortality as an exogenous given.

The years-to-live pyramid describes the demographic situation of a population under a different angle. It classifies the observed population into homogeneous subpopulations from the viewpoint of their survival.

In the case where the age pyramid is relatively balanced with the CPS pyramid (such as in 1982), the imbalance with the years-to-live pyramid therefore reflects ageing due to the reduced mortality of younger cohorts compared with older ones at the same age.

We are above all interested until now in the global imbalances between age classes, but the years-to-live pyramid of the year 1982 indicates that the imbalance between male and female stocks is of an entirely new magnitude [See for example figure 51. The fact that males live shorter lives than females is not new, but the growth in this gap is recent. The ratio between the mean remaining lifespan of the female population to that of the male population is $\frac{44.1}{40.2} \times 100=110$.

Unlike demographic projections that make hazardous hypotheses about changes in fertility, years-to-live pyramids make hypotheses only on mortality that are, excepting catastrophe, much more stable over time. They do not serve for the same ends but permit awareness of the same phenomena under a different angle and thus more completely. One could, for example, make hypotheses on changes in the age of retirement, divorce, etc., and decompose the years-to-live pyramid into active and inactive, married, widowed or divorced etc., and obtain new clarity. 


\section{Les contrastes régionaux les plus marqués}

Dans une étude régionale et encore plus dans une étude départementale le fait nouveau provient des migrations qui modifient singulièrement la structure d'une population, mais rappelons que la mortalité et la fécondité ont toujours eu un aspect régional bien spécifique.

Le croissant fertile du Nord existe encore et les régions les plus contrastées sont le Nord - Pas-de-Calais avec 2,5 enfants par femme et le Limousin avec 1,58 en 1982.

La mortalité est aussi plus importante dans le Nord, la Normandie et la Bretagne ; les plus grands écarts régionaux sont observés pour les hommes qui ont 67,3 ans d'espérance de vie en 1982 dans le Nord-Pas de Calais et 72,3 ans dans la région MidiPyrénées.

Fécondité et mortalité importantes peuvent alors se combiner pour donner une structure par âge jeune - cas du Nord - Pas-de-Calais-; fécondité faible et mortalité relativement faible donnent une structure plutôt vieille — cas du Limousin-. La combinaison est rarement aussi nette, et les phénomènes migratoires tant passés que récents modifient la classification.

Certaines zones comme celles du Sud-Est attirent les retraités, d'autres comme le Nord ou la Lorraine, touchées par la crise économique (sidérurgie et textile) se sont dépeuplées à tous les âges, d'autres, essentiellement du « rural profond » comme la BasseNormandie, l'Auvergne ou le Limousin sont aussi des terres d'émigration de jeunes, mais ces régions bénéficient d'une immigration dite de « retour au pays » de la part des retraités. Enfin, l'Ile-de-France est l'exemple classique d'une région essentiellement urbaine qui exerce à la fois une attraction pour les jeunes entre 20 et 30 ans et une répulsion, plus faible entre 25 et 35 ans et à l'âge de la prise de retraite (voir Courgeau and Lefebvre [1982]).

A ces phénomènes déjà complexes se mêlent des phénomènes historiques propres à la région ; ainsi le
We now see how the imbalances of the structure observed for the whole of France are often worse at the regional level.

\section{The most marked regional contrasts}

At the regional level, and even more so at the departmental level, migrations singularly modify population structure; but recall that mortality and fertility still have very specific regional aspects.

The northern fertile crescent still exists and the most contrasting regions are the Nord Pas-de-Calais with 2.5 children per female and Limousin with 1.58 in 1982.

Mortality is also more important in the Nord, Normandie, and Bretagne; the greatest regional differences are observed among males, with a life expectancy of 67.3 in Nord - Pas-de-Calais and 72.3 in Midi-Pyrénées.

High fertility and high mortality can combine to form a young age structure, as is the case of Nord - Pas-de-Calais; low fertility and relatively low mortality produce a rather old age structure as is the case of Limousin. The combination is rarely so clear, and migrations, both past and recent, may modify the ranking.

Certain zones, such as those of the South-East attract retirees, others like the Nord or Lorraine, touched by the economic crisis (the steel and textile industries) have depopulated at all ages, others, essentially the "deep rural" like the BasseNormandie, Auvergne or Limousin are also areas of youth emigration, but these regions also benefit from "back-to-the-country" immigration from retirees. Finally, the Ile-de-France is a classic example of an essentially urban area that at the same time has an attraction for young people aged 20 to 30 and a weaker repulsion between 25 and 35 and again at retirement ages (see Courgeau and Lefebvre [1982]).

These already-complex phenomena mix to- 

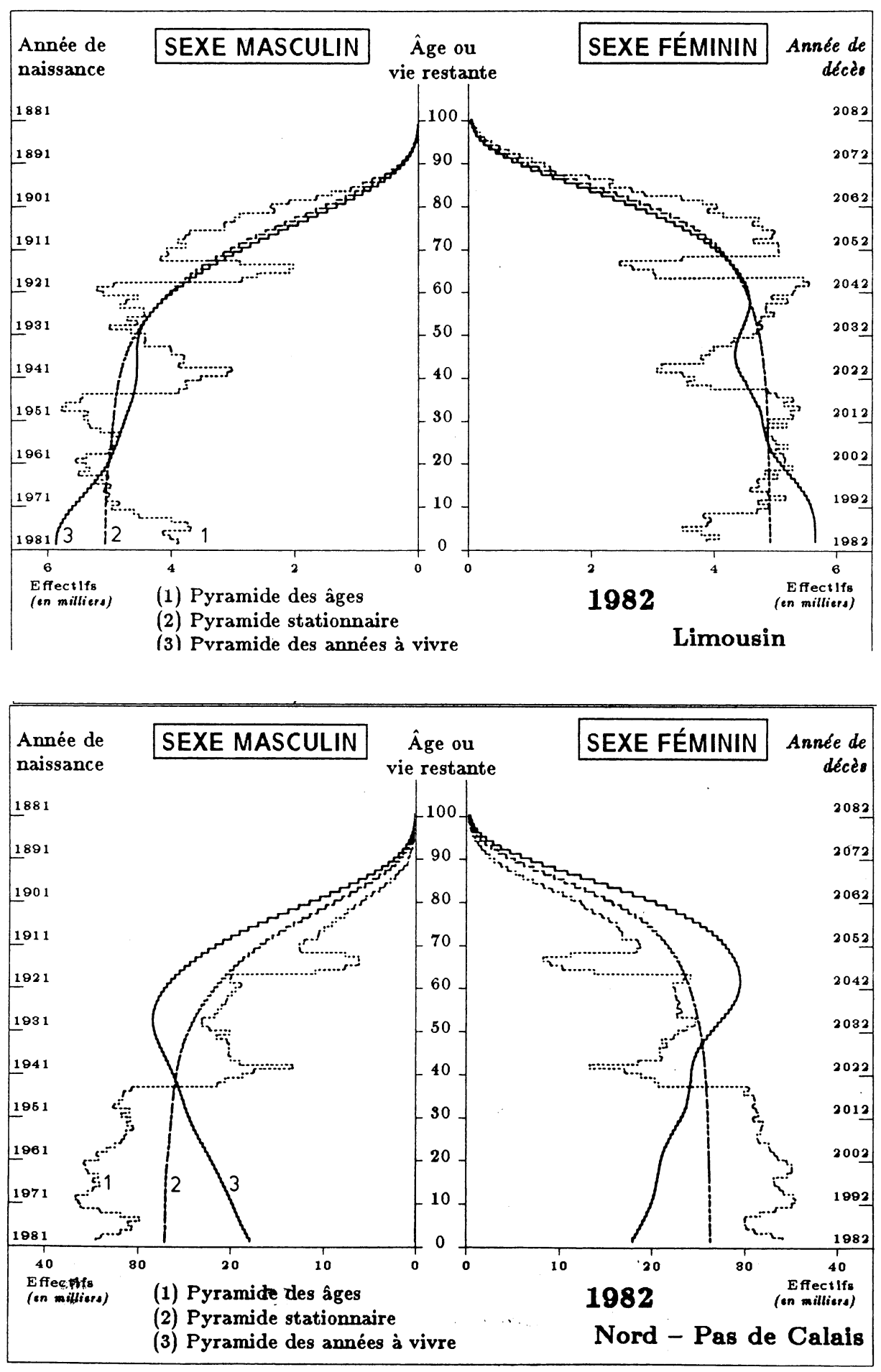

FIG. 8 : Pyramide des âges, pyramide stationnaire et pyramide des années à vivre au recensement de 1982 pour les régions du Limousin et du Nord - Pas-de-Calais.

FIG. 8: Age pyramid, stationary pyramid and remaining lifetime pyramid from the 1982 census for regions Limousin and Nord-Pas de Calais. 

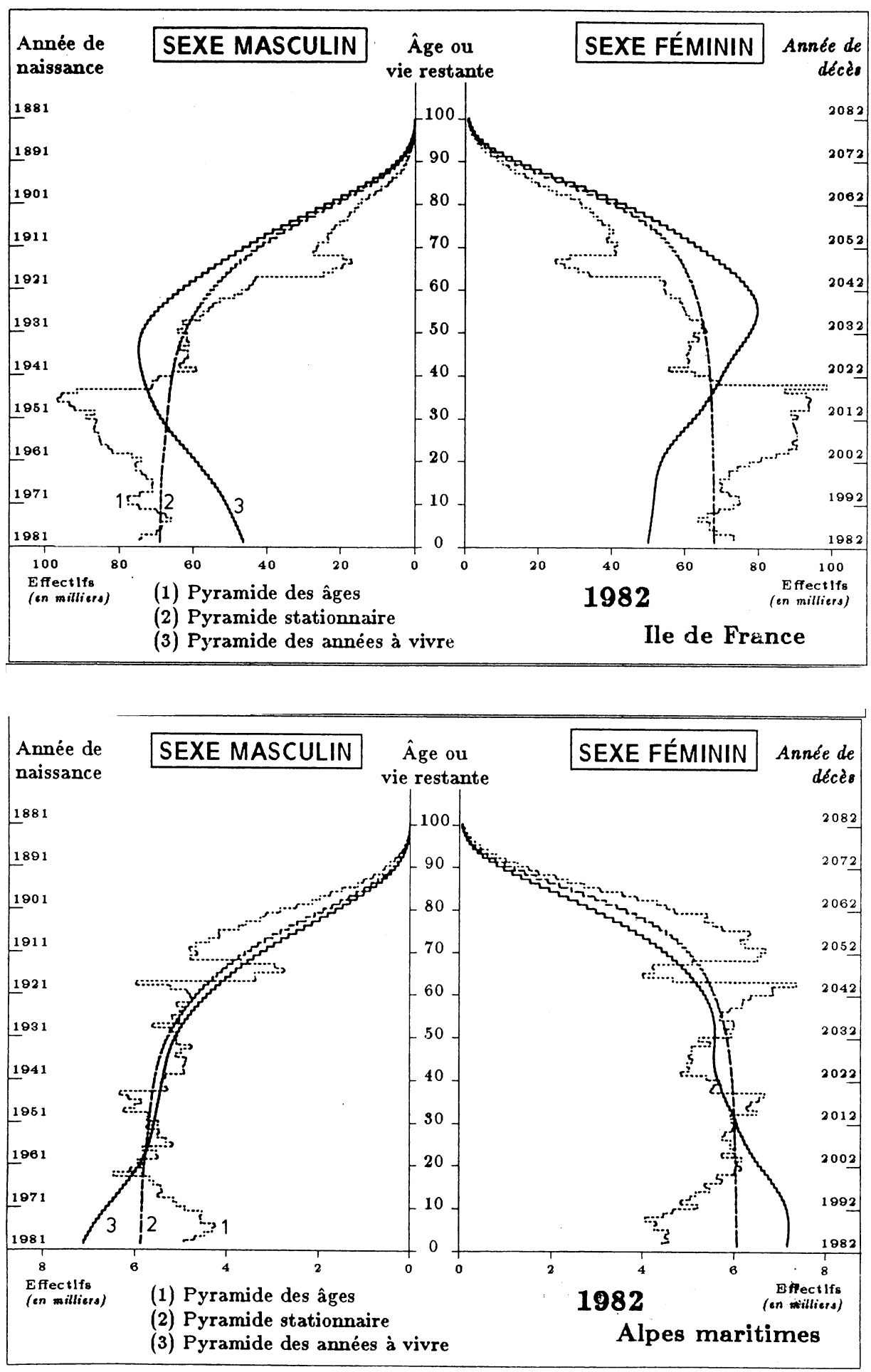

Fig. 9 : Pyramides des âges, pyramide stationnaire et pyramides selon la vie restante au recensement de 1982 pour la région de l'Ile-de-France et le département des Alpes-Maritimes.

FIG. 9: Age pyramid, stationary pyramid and remaining lifetime pyramid from the 1982 census for regions lle de France and Alpes-Maritimes. 
Limousin ou la Bretagne ont été très mobilisés durant la première guerre, et le déficit des classes creuses y est plus important qu'ailleurs. Ainsi, les pyramides des âges régionales sont beaucoup plus accidentées que la pyramide de la France prise dans son ensemble. Sans passer en revue les pyramides de toutes les régions, intéressons-nous aux régions les plus contrastées (voir Gaymu [1985]) en retenant la région du Limousin et le département des Alpes-Maritimes 12 pour les plus vieilles, et le Nord-Pas de Calais et l'Ile de France pour les plus jeunes. Nous n'avons pas tenu compte, pour simplifier, des particularités régionales en matière de mortalité, et calculer les pyramides stationnaires équivalentes, et les pyramides des années à vivre en supposant la mortalité constante et égale à celle de la mortalité de l'année 1982 pour la France entière.

TAB. 1 : Age moyen et DURÉE De vie Restante MOYENNE DE QUELQUES RÉGIONS FRANÇAISES TYPIQUES

\begin{tabular}{|lccc|}
\hline $\begin{array}{l}\text { Régions } \\
\text { ou } \\
\text { département }\end{array}$ & $\begin{array}{l}\hat{\text { gge }} \\
\text { moyen }\end{array}$ & $\begin{array}{l}\text { Durée de vie } \\
\text { restante } \\
\text { moyenne }\end{array}$ & $\begin{array}{l}\text { Rapport } \\
\text { x100 }\end{array}$ \\
\hline $\begin{array}{l}\text { Ile-de-France } \\
\text { Nord - }\end{array}$ & 35,5 & 43,5 & 120 \\
Pas-de-Calais & 35,0 & 44,5 & 128 \\
Limousin & 42,1 & 38,9 & 92 \\
Alpes-Maritimes & 43,1 & 38,0 & 88 \\
France (entière) & 36,3 & 42,7 & 116 \\
\hline
\end{tabular}

Nous pouvons alors remarquer sur les figures 8 et 9 que les contrastes entre les types de région sont beaucoup plus nets car la pyramide SVR lisse les à-coups de la pyramide des âges. Les indices (tableau 1) qui rapportent la durée de vie restante moyenne à la vie moyenne vécue ont des variations très importantes.

Le tracé de la pyramide des annéees à vivre d'une région n'a qu'un but descriptif et peut paraître moins justifié qu'au niveau national puisqu'une partie importante de la population ne restera pas dans la région jusqu'à sa mort. Mais l'argument prévaut aussi

12. Le département des Alpes-Maritimes est plus peuplé que la région du Limousin (Corrèze, Creuse et Haute-Vienne). gether with the individual regional history; thus, Limousin or Bretagne were very mobilized during World War I, and the deficits of the "classes creuse" are greater than elsewhere. Thus regional age pyramids are much more marked than the pyramid of France as a whole. Without delving into a review of the pyramid of each region, we interest ourselves with the most contrasted regions (see Gaymu [1985]), keeping the regions of Limousin and the department of AlpesMaritimes 12 as the oldest, and Nord - Pas-deCalais and the Ile-de-France as the youngest. We have not taken account, for the sake of simplicity, the regional peculiarities in mortality, and have calculated stationary-equivalent pyramids and years-to-live pyramids assuming mortality equal to that of all France for the year 1982. We can therefore say of the figures 8 and 9 that the contrasts between these two regional types are much clearer in the years-to-live pyramid, which

Table 1: Mean age Lived and Mean Remaining LIFESPAN IN SOME TYPICAL REGIONS OF FRANCE

\begin{tabular}{|c|c|c|c|}
\hline $\begin{array}{l}\text { Regions } \\
\text { or } \\
\text { departements }\end{array}$ & $\begin{array}{l}\text { Mean } \\
\text { years } \\
\text { lived }\end{array}$ & $\begin{array}{l}\text { Mean re- } \\
\text { maining } \\
\text { lifespan }\end{array}$ & $\begin{array}{l}\text { Ratio } \\
\times 100\end{array}$ \\
\hline Ile-de-France & 35.5 & 43.5 & 120 \\
\hline Nord - Pas-de-Calais & 35.0 & 44.5 & 128 \\
\hline Limousin & 42.1 & 38.9 & 92 \\
\hline Alpes-Maritimes & 43.1 & 38.0 & 88 \\
\hline France (national) & 36.3 & 42.7 & 116 \\
\hline
\end{tabular}

smooths the jagged profile of the age pyramid. The ratio (table 1) defined by the mean remaining lifespan and the mean years lived exhibits important variations. The profile of the years-to-live pyramid has a descriptive end, and may appear less justified than at the national level since a large part of the population will not stay in the same region until death. But this argument also holds for the age-pyramid, which translates a period situation without great value for the future. While it is

12. The department of Alpes-Maritimes has a higher population than the region of Limousin (Corrèze, Creuse et Haute Vienne). 


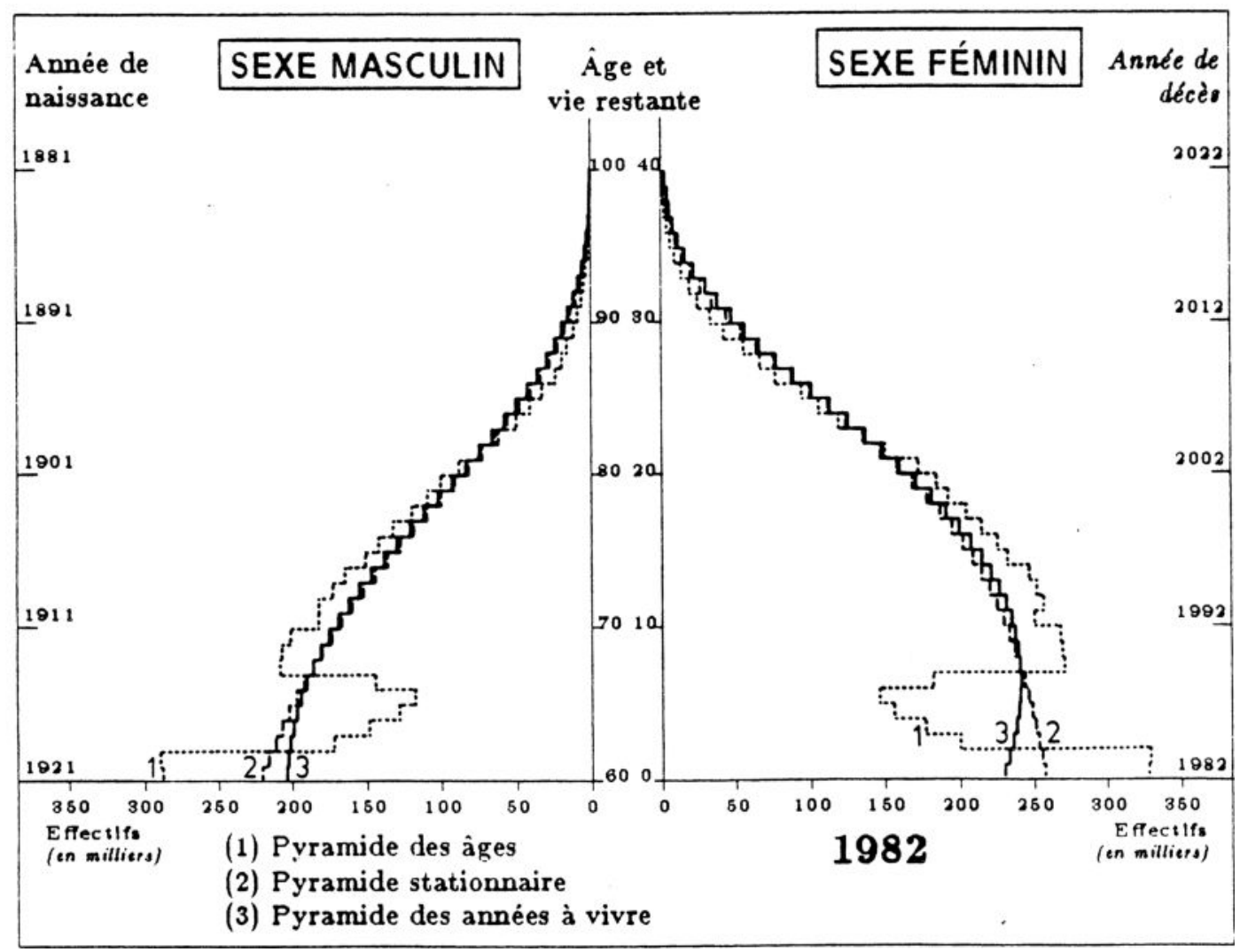

Fig. 10 : Pyramide des âges et pyramide des années à vivre des personnes âgées de plus de 60 ans en 1982 FIG. 10: Age pyramid and remaining lifetime pyramid, among population aged over 60 in 1982.

pour la pyramide des âges, qui traduit une situation ponctuelle sans grande valeur pour l'avenir. Autant il est aisé de distinguer dans une pyramide des âges les immigrés depuis une certaine date (la date du dernier recensement par exemple), autant il serait intéressant de distinguer dans la pyramide des années à vivre, les futurs émigrés avant une date prochaine (sur la base des taux d'émigration actuels par exemple).

Pour conclure cet article nous avons tenu à revenir à nos préoccupations initiales sur l'âge et la vie restante. Si pour l'ensemble de la population, le concept de vie restante nous a simplement permis de faire une statistique descriptive d'un genre nouveau, nous pensons que pour la population âgée, la vie restante devient une variable importante qui influe sans doute sur les comportements. easy to distinguish immigrants in an age pyramid that have arrived since a certain date (since the last census, for example), it would be interesting to distinguish in a years-to-live pyramid emigrants beyond some future date (on the basis of current emigration rates, for example).

To conclude this article we must return to our initial concern about age and and remaining lifetime. If for the whole population, the concept of remaining lifetime has simply permitted us to do a new kind of descriptive statistics, we think that for the elderly population, remaining lifetime should be an important variable that doubtless influences behavior.

We have therefore drawn in figure 10 the age pyramid and the years-to-live pyramid of only the 
Nous avons alors tracé sur la figure 10 la pyramide des âges et la pyramide des année; à vivre de la seule sous-population des per sonnes âgées de plus de 60 ans. Nous pouvons alors remarquer que l'énorme déficit des classes creuses observé sur la pyramide des âges est à peine visible sur la pyramide des années à vivre. Autrement dit même si la répartition par âge est très particulière, le critère de l'âge ne suffit pas à classer les hommes suivant leur risque maximum. L'âge est un critère fondamentale puisque le risque varie exponentiellement en fonction de celui-ci, mais la variance de l'âge au décès est très importante, ce qui explique que la pyramide des années à vivre soit lisse. Si on pouvait déjà classer les hommes suivant leur état de santé, on se rapprocherait plus de la pyramide selon la vie restante ; on connaîtrait mieux l'avenir individuel, et si nous parvenions à l'améliorer notre connaissance de l'avenir collectif serait élargie. population aged 60 and higher. We can thus comment that the enormous deficit of the "classes creuses" cohorts observed in the age-pyramid is barely visible in the years-to-live pyramid. In other words, even if an age distribution is very particular, the criterion of age is not sufficient to classify people according to maximum risk. Age is a fundamental criterion because risk varies exponentially as a function of it, but the variance in age at death is high, and this explains why the years-to-live pyramid is smooth. If one could also classify people by their health status, this would better approximate the years-to-live pyramid; one would better know the future of individuals, and if we managed to improve [individual health], then we would have a better understanding of the collective future.

\section{References}

Nicolas Brouard. Espérance de vie active, reprise d'activité féminine : un modèle. Revue économique, 31 (31):1260-1287, 1980. ISSN 0035-2764. doi: 10.3406/reco.1980.408577. URL http://www.persee.fr/ doc/reco_0035-2764_1980_num_31_6_408577.

Nicolas Brouard. Mouvements et modèles de population. IFORD, Yaoundé, Cameroun, Décembre 1985. URL https://hal .archives-ouvertes.fr/hal-01722705. (cours polycopié).

Gérard Calot. Le recensement de la Chine. Population et Sociétés, (180), May 1984.

Daniel Courgeau and Monique Lefebvre. Les migrations internes en France de 1954 à 1975. II.- Migrations et urbanisation. Population, (2):341-370, 1982.

Joëlle Gaymu. Les populations âgées en france au recensement de 1982. Population, (4-5):699-724, 1985.

Jacques Vallin. La mortalité par génération en France, depuis 1899. Number 63 in INED, Travaux et Documents. PUF, Paris, 1973.

\section{A Proof of the theorem on the equality of the age pyramid and years- to-live pyramid in the case of stationarity}

We give a translation of the theorem 4.1 and property II.4 (page 80) published in the Manual of the French Speaking School of Demography of the United Nations (IFord) in Yaounde (Cameroon).1989BROUARD, Nicolas.- Mouvements et modèles de population. - Yaoundé : Saint Paul, 1989. - 189 
p. : ill., couv. en coul.; $24 \mathrm{~cm}$. - (Les documents pédagogiques de l'IFORD). http://sauvy.ined. $\mathrm{fr} /$ brouard/enseignements/iford/mouvementetmodeles.pdf. Theorem numbering has been carried over from the original. An earlier version of the same proof but in discrete time was given to the students of IFoRD as an exercise, see the original scanned stencils of December 5th 1981 at https: //hal.archives-ouvertes.fr/cel-01722706,

\section{Pyramide des années à vivre}

Théorème 4 .2 Dans une population stationnaire on peut dénombrer autant d'individus agés de $x$ années, que d'individus ayant $x$ années à vivre.

Démonstration Dans une population stationnaire, le nombre d'individus âgés entre $x$ et $x+\mathrm{d} x$ années à un instant quelconque $t$ est $P(x) \mathrm{d} x=N S(x) \mathrm{d} x$.

Il suffit de calculer le nombre de décès attendus entre les instants $t+x$ et $t+x+\mathrm{d} x$, parmi la seule population présente à l'instant $t$, voir le diagramme de Lexis de la figure 11.

- sur les $P(y) \mathrm{d} y=N S(y) \mathrm{d} y$ individus présents à l'instant $t, N S(y) \mathrm{d} y \times \frac{S(y+x)}{S(y)}$ survivront $x$ années, et $N S(y) \mathrm{d} y \times \frac{S(y+x)}{S(y)} \times \mu(y+x) \mathrm{d} x$ décèderont entre les instants $t+x$ et $t+x+\mathrm{d} x$.

- sur l'ensemble de la population présente à l'instant $t$, il suffit de sommer sur tous les âges $y$ :

$$
\begin{array}{r}
N \int_{y=0}^{\infty} S(y) \mathrm{d} y \frac{S(y+x)}{S(y)} \mu(y+x) \times \mathrm{d} x= \\
N \int_{y=0}^{\infty} S(y+x) \mu(y+x) \mathrm{d} y \times \mathrm{d} x \\
=-N \int_{y=0}^{\infty} S^{\prime}(y+x) \mathrm{d} y \times \mathrm{d} x \\
=-N[S(x+y)]_{y=0}^{\infty} \times \mathrm{d} x \\
=N S(x) \times \mathrm{d} x
\end{array}
$$

Il est intéressant de tracer le graphe de la distribution de la population non pas suivant l'âge, mais suivant le délai qui lui reste à vivre; nous pouvons représenter cette distribution sous la forme d'une pyramide et nous l'avons intitulée pyramide des années à

\section{The years-to-live pyramid}

Theorem 4.2 In a stationary population one can count as many individuals aged $x$ years, as individuals with $x$ years left to live.

Proof In a stationary population, the number of individuals aged between $x$ and $x+\mathrm{d} x$ years at any time $t$ is $P(x) \mathrm{d} x=N S(x) \mathrm{d} x$.

It suffices to calculate the number of deaths expected between the calendar dates $t+x$ and $t+x+\mathrm{d} x$, from only the population present at time $t$, see the Lexis diagram of figure 11

- out of the $P(y) \mathrm{d} y=N S(y) \mathrm{d} y$ individuals alive at time $t, N S(y) \mathrm{d} y \times \frac{S(y+x)}{S(y)}$ will survive for $x$ years, and $N S(y) \mathrm{d} y \times \frac{S(y+x)}{S(y)} \times$ $\mu(y+x) \mathrm{d} x$ will die between times $t+x$ and $t+x+\mathrm{d} x$.

- Of the whole population present at time $t$, just sum over all ages $y$ :

$$
\begin{array}{r}
N \int_{y=0}^{\infty} S(y) \mathrm{d} y \frac{S(y+x)}{S(y)} \mu(y+x) \times \mathrm{d} x= \\
N \int_{y=0}^{\infty} S(y+x) \mu(y+x) \mathrm{d} y \times \mathrm{d} x \\
=-N \int_{y=0}^{\infty} S^{\prime}(y+x) \mathrm{d} y \times \mathrm{d} x \\
=-N[S(x+y)]_{y=0}^{\infty} \times \mathrm{d} x \\
=N S(x) \times \mathrm{d} x
\end{array}
$$

It is interesting to draw the graph of the distribution of the population, not according to age, but according to the time remaining to live; we can represent this distribution in the form of a pyramid and we have called it a years-to-live pyramid. 


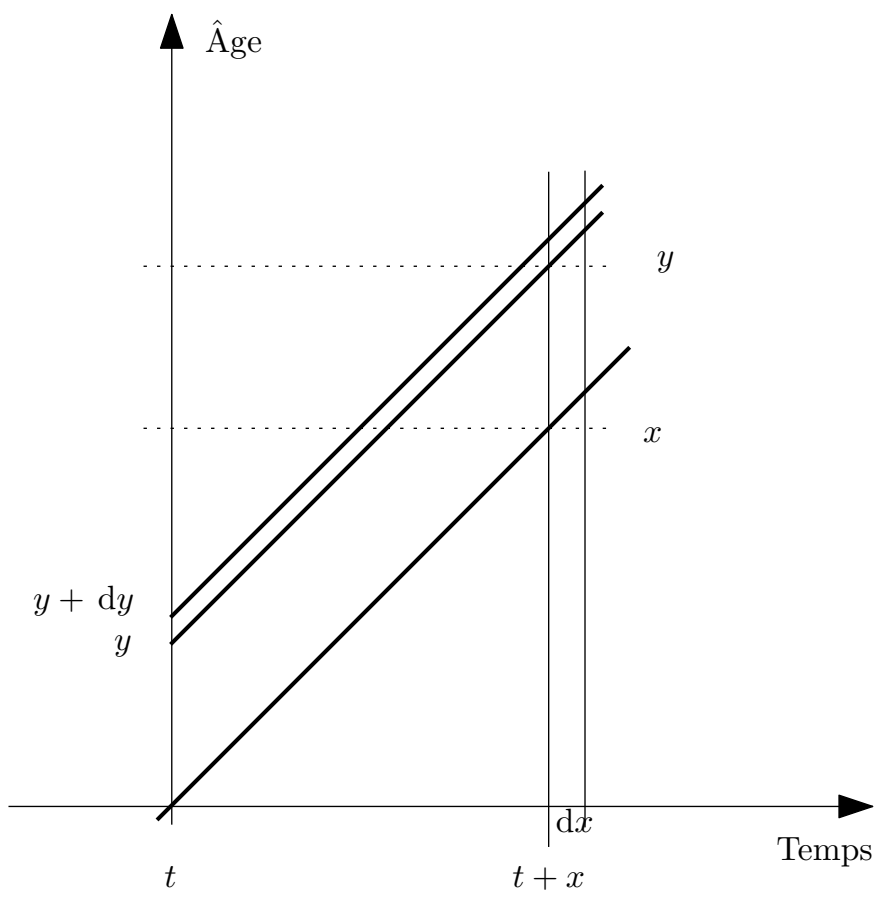

FIG. 11 : Diagramme de Lexis pour le calcul des décès.

FIG. 11: Lexis diagram for the computation of deaths.

vivre. La propriété démontrée ci-dessus s'énonce aus- The property demonstrated above can be stated si : as follows:

Propriété II .4 Dans une population stationnaire, Property II .4 In a stationary population, the la pyramide des âges et la pyramide des années à vivre age pyramid and years-to-live pyramid are identisont identiques. cal. 